\title{
PRZEKŁADY KSIAŻKI ZAGRANICZNEJ W POLSCE W LATACH 1991-2010 W ŚWIETLE STATYSTYKI
}

\author{
Anna Musioł \\ Instytut Informacji Naukowej \\ i Bibliotekoznawstwa \\ Uniwersytet Wrocławski
}

Książka zagraniczna w Polsce 1991-2010; przekłady obce w Polsce 1991-2010

Transformacja ustrojowa rozpoczęta w Polsce w 1989 r. w sposób zasadniczy zmieniła dostęp do książki zagranicznej. Lata dziewięćdziesiąte to czas szerokiego otwarcia na literaturę zagraniczna, niedostępną w okresie wcześniejszym, to także okres komercyjnego podejścia do działalności wydawniczej. Pojawiają się nowi wydawcy, rynek prywatyzuje się. Książka traktowana jest jak towar, na którym można zarobić, co potwierdzają reedycje przekładów, które w latach wcześniejszych odniosły duży sukces (np.: Sto lat samotności Gabriela Garcii Márqueza, Blaszany bębenek Güntera Grassa, Folwark zwierzęcy Georga Orwella czy Ania z Zielonego Wzgórza Lucy M. Montgomery). W wyniku zmian na rynku wydawniczym zmieniaja się też zainteresowania czytelnicze. Ogromną popularność zaczyna zdobywać literatura popularna: sensacyjna, romansowa, erotyczna. Wydawcy staraja się jak najszybciej odpowiedzieć na te oczekiwania. Według oceny znawców, obecnie polscy odbiorcy moga poznać światowe bestsellery prawie w tym samym czasie, co oryginały ${ }^{1}$.

Analizując „Ruch Wydawniczy w Liczbach”, można stwierdzić, że w latach 1991-2010 ogólna liczba tłumaczeń na język polski wynosiła 85468 tytułów. Najwięcej przekładów zanotowano w roku 2000, a następnie w latach 20072010 (wykres 1).

Porównując dane z roku 1991 i 2010, można stwierdzić, że liczba przekładów zwiększyła się ponad czterokrotnie, przy czym w roku 2008 był to nawet wzrost pięciokrotny.

Dynamika przekładów książki zagranicznej w stosunku do książki polskiej kształtowała się niejednorodnie. Największy wzrost nastapił w roku 1992 do roku 1993. W 1992 roku tłumaczenia stanowiły 18,62\%, natomiast już rok później wskaźnik procentowy wzrósł do $25,44 \%$. Średnio w ciagu dwudziestoletniego okresu stosunek liczby przekładów do liczby tytułów publikacji krajowych wynosił 22 do $78 \%$, czyli nieco ponad $1 / 5$ wszystkich wydanych książek stanowiły tłumaczenia. Najwięcej w roku $2000-26,13 \%$, najmniej w roku $1991-13,51 \%$.

${ }^{1}$ E. Skibińska: Kuchnia tłumacza. Studia o polsko-francuskich relacjach przekładowych. Kraków 2008, s. 91. 


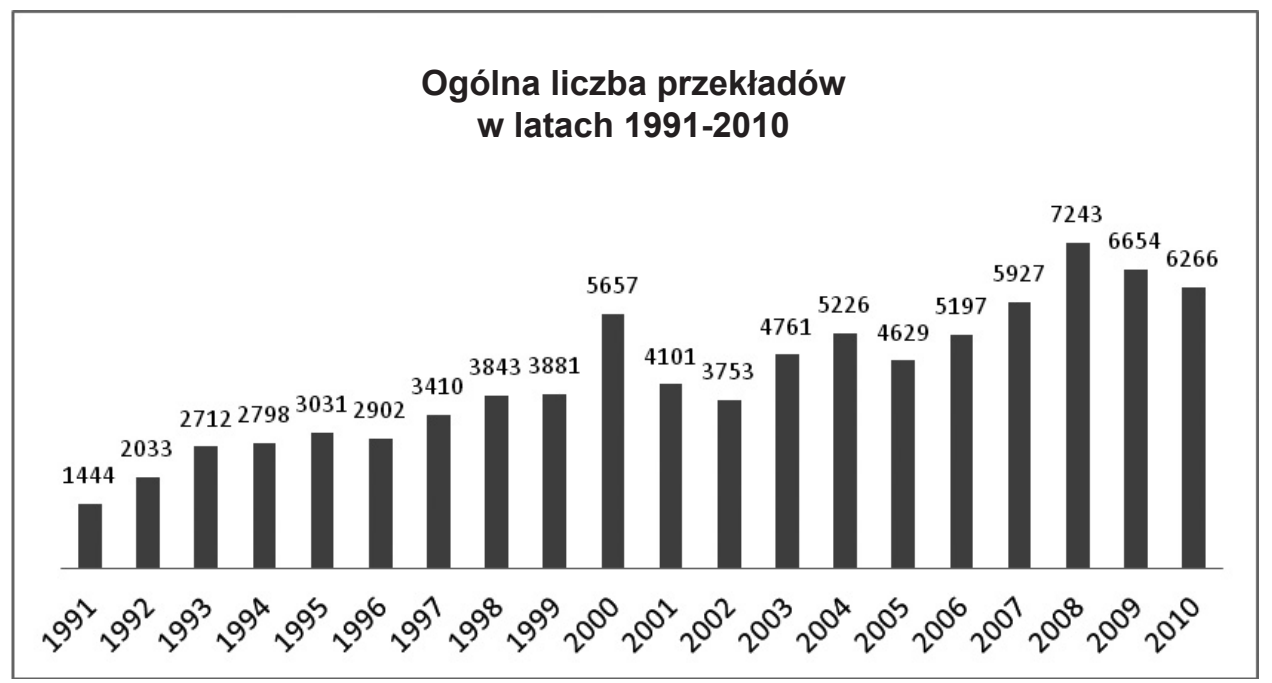

Wykres 1

W przypadku średniej zliczanej dla okresów pięcioletnich najwyższy wskaźnik udziału tłumaczeń można zaobserwować dla lat 2006-2010 i jest to $23,01 \%$. Proces ten ilustruje wykres 2.

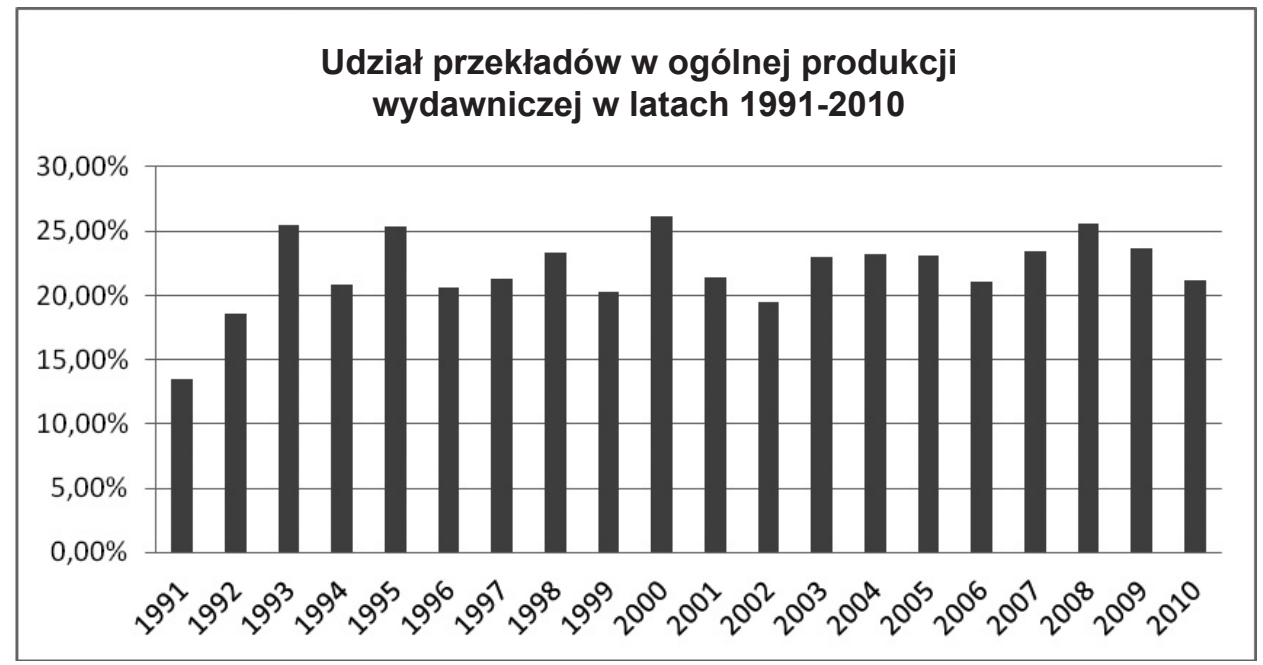

Wykres 2

Stosunek liczby przekładów do liczby tytułów rodzimych jest w Polsce bardzo wysoki. W Niemczech średni procent przekładów wśród pierwszych wydań wynosi 7,15\%, we Francji w stosunku do ogółu sprzedawanych książek - 14,2\%. Oczywiście, w wymienionych krajach na liczbę tłumaczeń wpływa fakt, że wielu 
zagranicznych książek nie trzeba tłumaczyć, ponieważ pochodzą z tego samego obszaru językowego².

Skutki transformacji ustrojowej zauważalne sa w statystyce języków przekładów (wykres 3). W latach 1991-2010 na ogólną liczbę 85468 tytułów 72653 stanowiły przekłady z pięciu języków: angielskiego, niemieckiego, francuskiego, hiszpańskiego, rosyjskiego. Na pozostałe języki przypada liczba 12815 tytułów. Dominowały tłumaczenia z języka angielskiego. Łącznie ukazało się 51280 tytułów, co stanowi $60 \%$ ogólnej liczby przekładów. Na drugim miejscu znajduja się tłumaczenia z języka niemieckiego, których wydano łącznie 10802 tytuły, co stanowi $13 \%$ udziału w rynku książki zagranicznej w Polsce. Przekłady z języka francuskiego wynoszą $8 \%$, a tłumaczenia z rosyjskiego i z hiszpańskiego po około $2 \%$ ogólnej liczby przekładów.

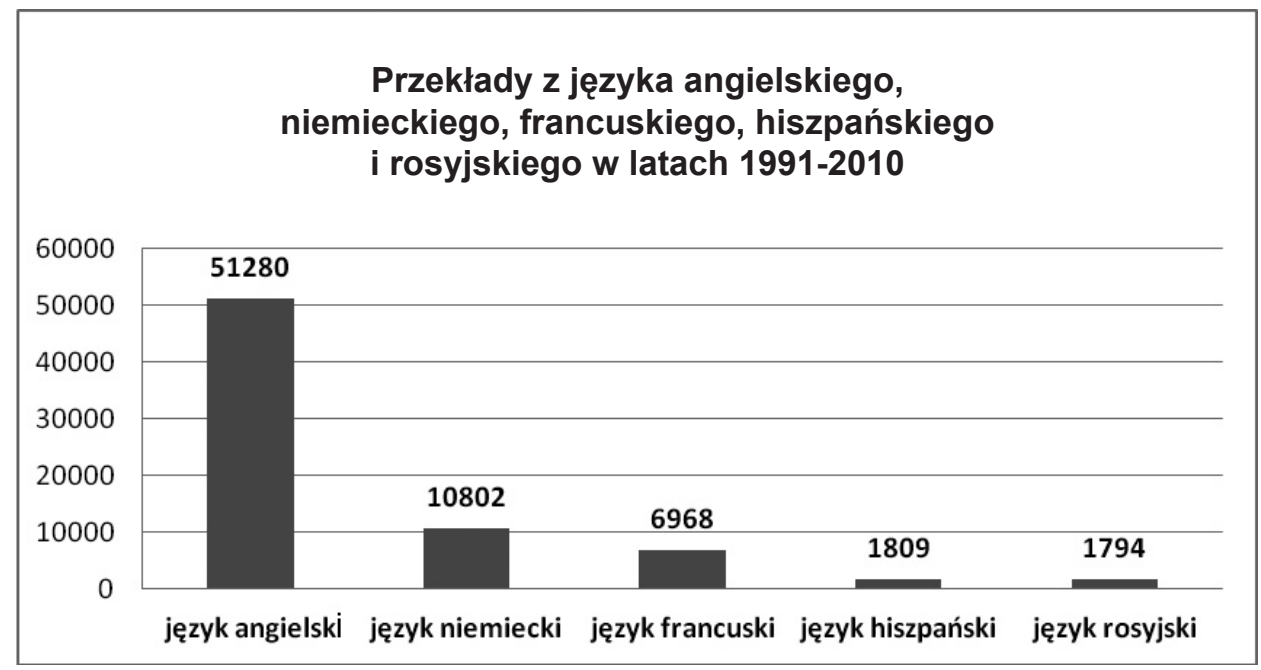

Wykres 3

\section{Przekłady z języka angielskiego}

Od epoki Oświecenia do czasów współczesnych tłumaczenia z języka angielskiego maja ogromny wpływ na rozwój polskiej nauki i kultury. Po II wojnie światowej działalność przekładowa ograniczona była przez cenzurę. Po roku 1989 zniesiono centralny system zarządzania produkcją i dystrybucją książki. Zainteresowanie książką angielskojęzyczną jest w Polsce wyjątkowo wysokie, co ilustruje wykres 4 . Wynika to z zasięgu oddziaływania języka angielskiego w świecie. Niewielkie spadki w roku 1996, 1998 czy 2001 i 2002 lub 2005 w stosunku do roku poprzedzającego nie zmieniają zasadniczej tendencji wzrostowej.

Najwięcej przekładów wydano w 2008 r. W latach dziewięćdziesiątych łącznie ukazało się 19255 przekładów, w następnym dziesięcioleciu 32 025, a więc średnio 3202 przekłady rocznie. Ten wynik zapewnia dominację publikacji anglojęzycznych w Polsce. Wśród tłumaczeń z języka angielskiego dominuje

${ }^{2}$ Raport opracowany na zlecenie Ministerstwa Kultury i Dziedzictwa Narodowego. [online]. [dostęp: 14.07.2011]. Dostępny w World Wide Web: <http://www.ebib.info/images/file/ ksiazka_raport_w_pelna_pdf.pdf $>$. 


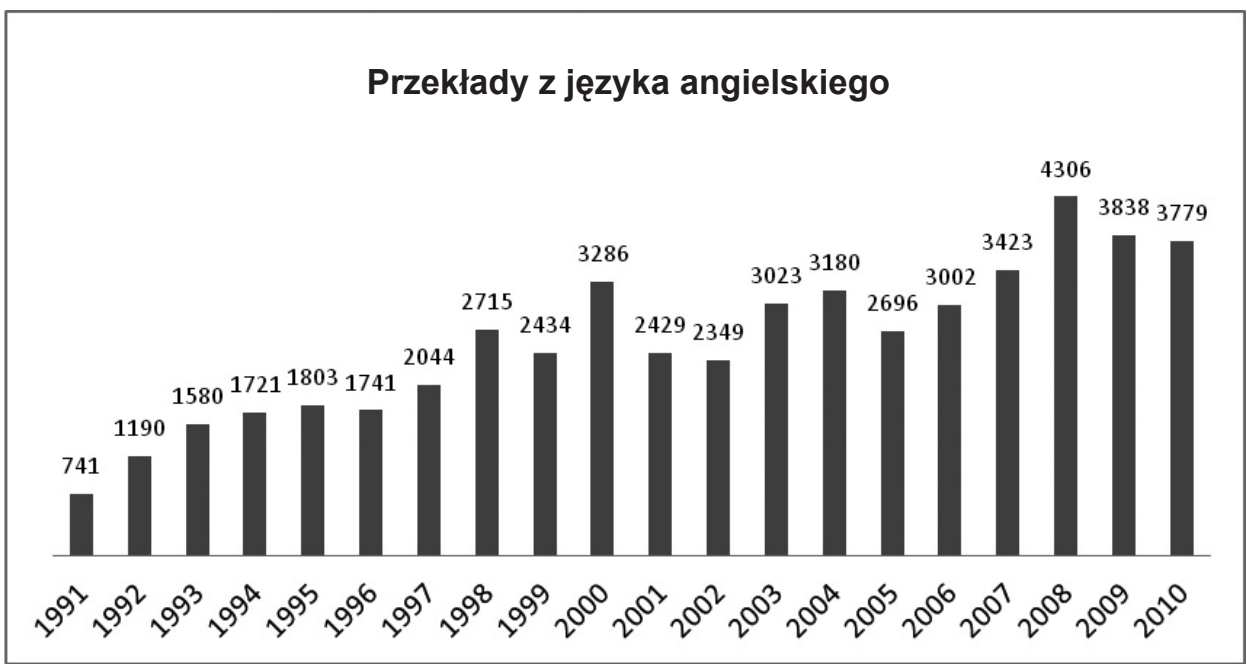

Wykres 4

literatura piękna. Przekłady beletrystyki stanowią 50\% wszystkich tłumaczeń (wykres 5).

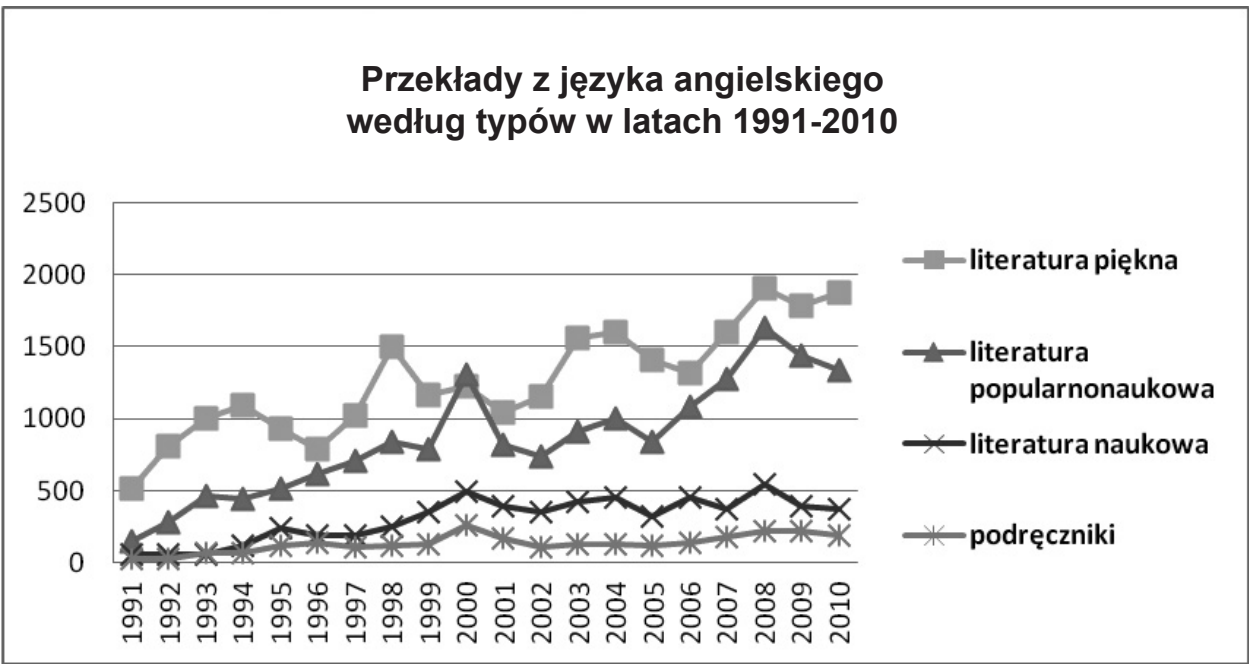

Wykres 5

W pierwszym okresie lat dziewięćdziesiątych zainteresowanie literaturą piękną amerykańska, angielską, australijska, kanadyjską systematycznie wzrastało do 1994 r. Po tym okresie nastapił spadek, być może minał pierwszy entuzjazm związany z pojawieniem się zachodniej literatury, na przykład w latach 19951997 produkcja wydawnicza Harlequina zmniejszyła się ponad dwukrotnie ${ }^{3}$. Dużym zainteresowaniem cieszą się przekłady literatury popularnonaukowej,

${ }^{3}$ Ł. Gołębiewski: Księgarnia bestsellerów. „Wprost” 1998, nr 40, s. 122-123. 
których w latach 1991-2010 wydano łącznie 17198 tytułów, co stanowi 33\% ogółu dzieł tłumaczonych. W XX i XXI wieku język angielski stał się powszechnym językiem nauki i kultury, dlatego wydawcy chętnie publikuja przekłady literatury naukowej. W latach 1991-2010 wydano łącznie 6095 tytułów, średnio 580 pozycji rocznie. Dane liczbowe wykazują wyraźną różnicę w liczbie przekładów dwóch dekad. W latach dziewięćdziesiątych publikowano średnio 201 tytułów, w kolejnym dziesięcioleciu liczba ta wzrosła dwukrotnie. Wśród różnych typów publikacji najrzadziej tłumaczono podręczniki, w ciągu dwudziestu lat wydano 2688 pozycji.

\section{Przekłady z języka niemieckiego}

Na polsko-niemieckie związki literackie w XX wieku miały wpływ doświadczenia wojny i okupacji oraz polityka kulturalna władz PRL. Choć już po zakończeniu II wojny światowej na polskim rynku wydawniczym opublikowano reedycje tłumaczeń wydanych przed rokiem 1939, to decydujący wpływ na repertuar przekładów miały władze Niemieckiej Republiki Demokratycznej. W latach pięćdziesiątych na polskim rynku wydawniczym ukazało się niewiele przekładów z Austrii i Szwajcarii, ponieważ wyłączne prawa do tłumaczeń miały wydawnictwa z Republiki Federalnej Niemiec.

W latach pięćdziesiątych dominowały przekłady dzieł o tematyce antyfaszystowskiej i socjalistycznej. Najczęściej tłumaczono utwory autorów pochodzących z Niemieckiej Republiki Demokratycznej: Willego Bredela, Stefana Heyma, Adama Scharrera. W latach sześćdziesiątych i siedemdziesiątych wciąż nie zezwalano na przekłady publikacji, które uznawano za antypolskie. Blaszany bębenek Güntera Grassa został oficjalnie opublikowany w Polsce dopiero w 1983 r. Do tematów zakazanych należała również problematyka dawnych ziemi niemieckich. Muzeum ziemi ojczystej Siegfrieda Lenza (1978) w Polsce ukazało się dopiero w $1991 \mathrm{r}$.

Najlepszy okres współpracy polskich i niemieckich wydawców datuje się po 1989 roku. Współcześnie polscy wydawcy należą do najchętniej kupujących licencje do niemieckich książek. W okresie od 1991 do 2010 r. wydano łącznie 10802 tytuły (wykres 6). W latach dziewięćdziesiątych utrzymywała się tendencja wzrostowa. Niewielki spadek odnotowano w 1998 r., liczba tłumaczeń spadła o 73 tytuły. Momentem przełomowym był rok 2000, w którym nastapił największy wzrost liczbowy. Średnio w pierwszej dekadzie omawianego okresu rocznie tłumaczono 417 pozycji. Analiza ilościowa drugiej dekady wykazała wzrost zainteresowania przekładami z języka niemieckiego. W latach 20012010 tłumaczono rocznie średnio 663 tytuły.

Największą popularnością na polskim rynku wydawniczym cieszy się niemiecka literatura popularnonaukowa (wykres 7). W ostatnim dwudziestoleciu opublikowano 5915 tytułów, średnio 296 rocznie. Najczęściej tłumaczone są niemieckie poradniki o domu, ogrodzie, motywacji, zdrowiu czy stylu życia ${ }^{4}$. Do kręgu zainteresowań wydawców polskich należą także publikacje niemieckie

${ }^{4}$ S. Łupak: Literatura jak futbol. „Gazeta Wyborcza” 2006, nr 115, s. 14. 


\section{Przekłady z języka niemieckiego}

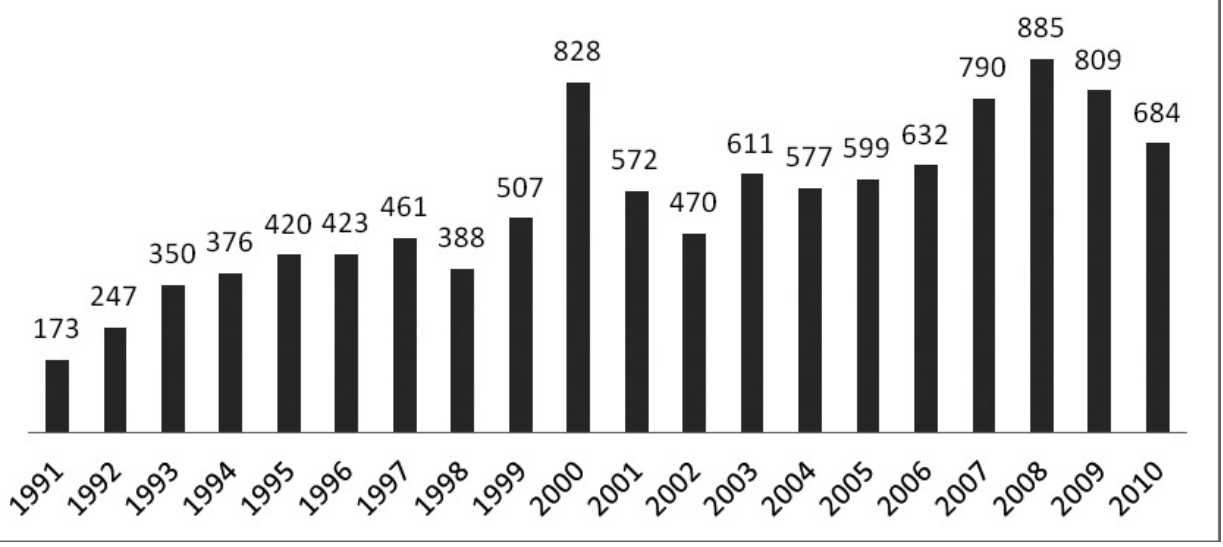

Wykres 6

opisujące wydarzenia z dziejów mitologii, archeologii, kryminologii, sensacji5 ${ }^{5}$ W latach 1991-1995 zaobserwowano stały wzrost publikacji popularnonaukowych, które stanowiły odpowiedź na tego typu zapotrzebowanie wśród polskich czytelników po okresie transformacji. Pierwszy spadek nastapił w roku 1996, ale liczba tytułów spadła nieznacznie (o 10 pozycji). Największy wzrost nastapił w roku 2000 (o 189 tytułów). W drugiej dekadzie średnio rocznie wydawano 385 pozycji.

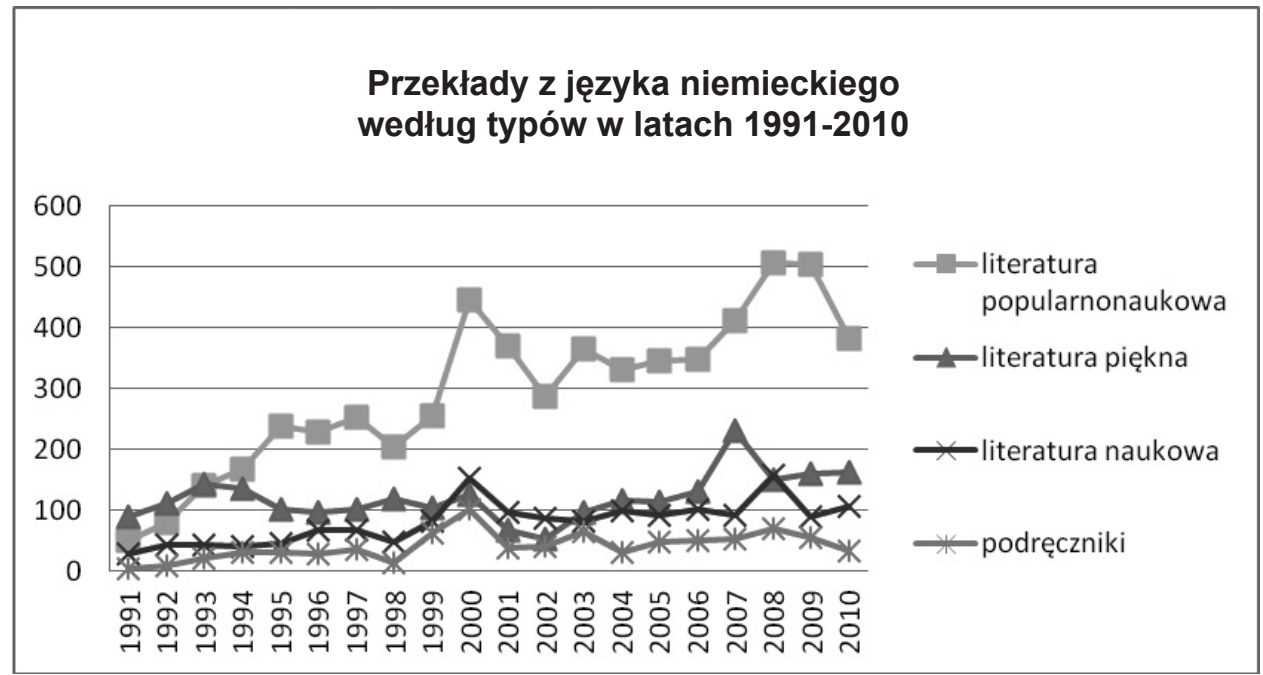

Wykres 7

${ }^{5}$ E. Połczyńska, C. Załubska: Bibliografia przekładów z literatury niemieckiej na język polski 1800-2000. Tom 4: 1991-2000. Poznań 2005, s. 16-17. 
Po literaturze popularnonaukowej największym zainteresowaniem wydawców cieszy się beletrystyka. W latach 1991-2000 pierwsze miejsce pod względem liczby tłumaczonych tytułów zajęła autorka kilkuset romansów i powieści popularnych Hedwig Courths-Mahler. Od lat dziewięćdziesiątych zaobserwowano też wzrost zainteresowania wznowieniami niemieckojęzycznych klasyków: Johanna Wolfganga Goethego, Tomasza Manna czy Franza Kafki ${ }^{6}$. W latach 1991-2010 na polskim rynku wydawniczym łącznie wydano 2418 tytułów literatury pięknej, średnio 121 pozycji rocznie. Moment kryzysowy miał miejsce w 2002 r.: liczba przekładów spadła do zaledwie 54 tytułów. Natomiast najwięcej tłumaczeń ukazało się w 2007 r. - 232 pozycje. Duży wpływ na kształt repertuaru przekładów niemieckiej literatury pięknej miało przyznanie Literackiej Nagrody Nobla Günterowi Grassowi w 1999 r. i Elfriede Jelinek w 2004 r.

Na polskim rynku wydawniczym istnieje również zapotrzebowanie na niemiecką literaturę naukowa. W latach 1991-2010 przetłumaczono łącznie 1634 tytuły. Dużym zainteresowaniem cieszą się przekłady z filozofii, psychologii i nowoczesnej pedagogiki ${ }^{7}$. Podobnie jak w pozostałych typach literatury, w roku 2000 nastapił gwałtowny skok: liczba tytułów wzrosła do 154 pozycji. Najrzadziej w Polsce tłumaczone są z języka niemieckiego podręczniki. W ciagu ostatniego dwudziestolecia łącznie przetłumaczono 835 tytułów. W pierwszej dekadzie średnio rocznie wydawano 35 pozycji, w następnej - 49 .

\section{Przekłady z języka francuskiego}

Polscy czytelnicy zawsze interesowali się literaturą powstającą we francuskim kręgu kulturowym, przypomnijmy choćby dzieła klasyków francuskich w tłumaczeniu Tadeusza Boya-Żeleńskiego. Zaraz po zakończeniu II wojny światowej przystapiono do wznawiania przedwojennych przekładów literatury francuskiej, publikowano tłumaczenia powstałe w okresie okupacji oraz wydawano uzupełnienia edycji klasyków francuskich. Po roku 1956 na polskim rynku wydawniczym dużym zainteresowaniem cieszyły się tłumaczenia dzieł reprezentujących egzystencjalizm oraz nowe techniki narracyjne. W tym okresie pojawiły się np. Dżuma i Upadek Alberta Camusa czy Dramaty Jeana-Paula Sartre'a. W okresie od roku 1956 do 1986 polscy czytelnicy mogli poznać to, co we Francji uznano za najbardziej wartościowe. W tym czasie w Polsce wydano 48 przekładów laureatów najważniejszych francuskich nagród literackich ${ }^{8}$. W latach 1991-2010 łącznie wydano w Polsce 6968 przekładów z języka francuskiego, średnio 348 tytułów rocznie (wykres 8). Lata dziewięćdziesiąte to okres stabilizacji. Wyraźny skok nastapił w roku 2000 , kolejny porównywalny to rok 2009. Średnio rocznie w drugiej dekadzie na polskim rynku wydawniczym opublikowano 405 nowości.

Najczęściej wydawcy decydowali się na zakup praw do tłumaczeń literatury popularnonaukowej. W omawianym czasie ukazało się 3315 publikacji tego typu (wykres 9).

\footnotetext{
${ }^{6}$ Ibidem, s. 17.

7 Ibidem, s. 17.

${ }^{8}$ E. Skibińska: Kuchnia tłumacza..., op. cit., s. 100.
} 


\section{Przekłady z języka francuskiego}

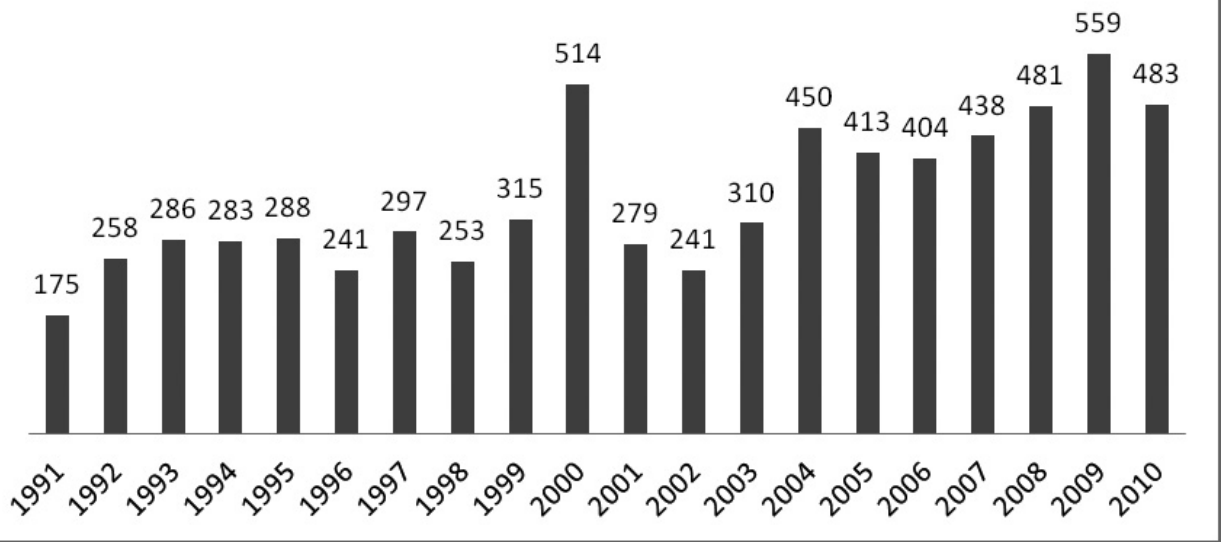

Wykres 8

\section{Przekłady z języka francuskiego według typów w latach 1991-2010}

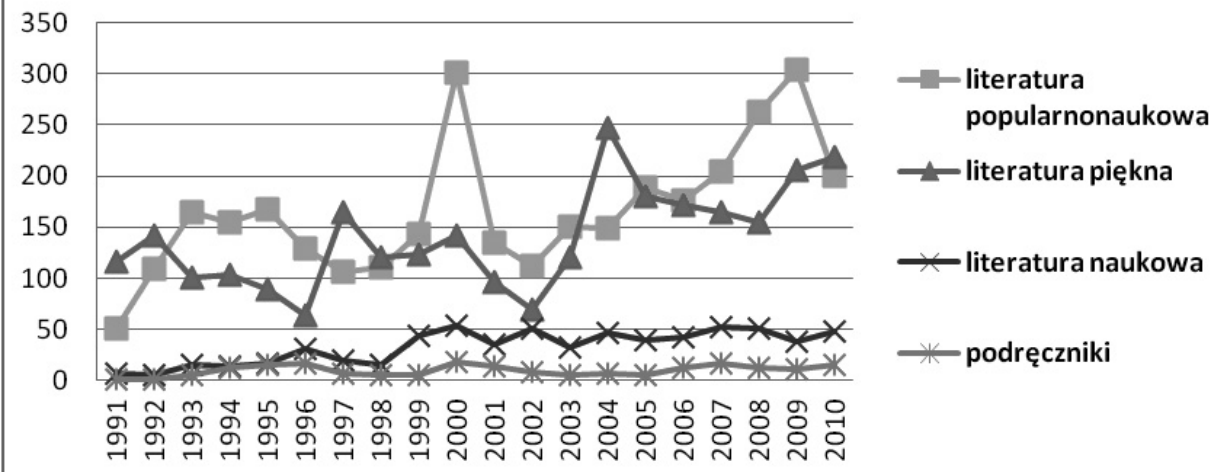

Wykres 9

Podobnie jak w przypadku ogólnej produkcji, rok 2000 przyniósł zaskakujący wzrost: liczba tłumaczeń zwiększyła się niemal dwukrotnie. W kolejnych latach zauważalna jest tendencja rosnąca. Najwięcej przetłumaczono literatury popularnej, na drugim miejscu znalazła się beletrystyka. Obok powieści Honoriusza Balzaka, Aleksandra Dumasa, Juliusza Verne'a ukazywały się dawne bestsellery Gastona Leroux czy Michela Zevaco. Według znawców literatury francuskiej stosunkowo niskie zainteresowanie tą literatura jest skutkiem trudności polskich wydawców w rozpoznaniu francuskiego rynku wydawniczego. Obecnie wydawnictwa francuskie zastanawiają się nad wprowadzeniem większej liczby 
tytułów w oryginale ${ }^{9}$. Również francuska literatura naukowa nie jest w Polsce zbyt licznie reprezentowana. W badanym okresie przetłumaczono na język polski zaledwie 659 tytułów, średnio 32 publikacje rocznie. Najwięcej, bo 53, ukazały się w roku 2000.

\section{Przekłady z języka hiszpańskiego}

W latach 1991-2010 losy publikacji hiszpańskojęzycznych były dość zmienne, choć z ogólną tendencją wzrostową. Należy jednak podkreślić, że daleko jeszcze do szczytu popularności, jaki przypadł na drugą połowę lat siedemdziesiątych ubiegłego wieku. W latach 1960-1980 ze względu na bardzo dużą liczbę przekładów literatury hiszpańskojęzycznej Polska zajmowała drugie miejsce w Europie po Republice Federalnej Niemiec ${ }^{10}$. W ciagu ostatnich 20 lat na polskim rynku wydawniczym łącznie ukazało się 1809 tłumaczeń, co daje średnią roczną 90 tytułów (wykres 10). Największy spadek odnotowano na przełomie lat 2004-2005: liczba tytułów spadła o 55 pozycji. Natomiast największy wzrost nastapił w latach 2005-2006, wówczas liczba przetłumaczonych publikacji wzrosła o 50 tytułów.

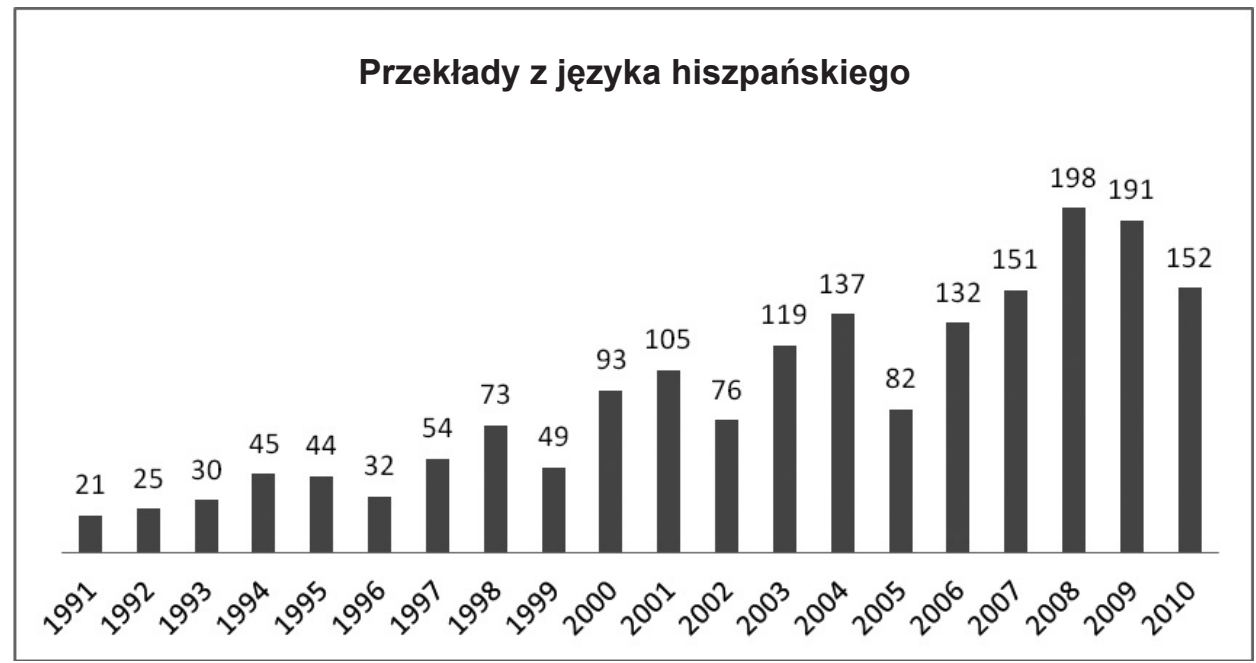

Wykres 10

Lata dziewięćdziesiąte to wyraźny okres stagnacji. Średnio rocznie wydawano zaledwie 41 tytułów. Aktywność nowo powstałych wydawnictw była niewielka. Państwowy Instytut Wydawniczy utracił w pierwszym okresie lat dziewięćdziesiątych prawo do wznowień przekładów, m.in. Julio Cortázara

${ }^{9}$ M. Kowalska, A. Zawadzki: O kondycji literatury najnowszej. Polsko-francuskie spotkania literackie. Kraków 2006, s. 88.

${ }^{10}$ A. Hutnikiewicz, A. Lam: Literatura polska XX w. Przewodnik encyklopedyczny. Tom 2. Warszawa 2000, s. 477. 
i Gabriela Garcii Márqueza11. Wzrost popularności przekładów hiszpańskojęzycznych zauważalny jest po 2000 r., kiedy ukazywało się rocznie średnio 130 tłumaczeń. Wśród różnych typów przekładów publikacji dominuje hiszpańskojęzyczna literatura piękna, choć na początku lat dziewięćdziesiątych ubiegłego wieku cieszyła się jeszcze umiarkowanym zainteresowaniem wydawców (wykres 11). W pierwszym pięcioleciu ukazywało się średnio rocznie 15 tytułów. W pierwszej dekadzie po transformacji wydawano głównie wznowienia. Dużą popularnością cieszyły się tłumaczenia autorów znanych przede wszystkim z lat siedemdziesiątych, wyjatkiem były powieści Isabel Allende i Laury Esquivel. Jednak w kolejnej dekadzie zaczęły pojawiać się publikacje autorów wcześniej nieznanych polskim czytelnikom ${ }^{12}$. W latach 2000-2010 średnio rocznie opublikowano 64 tytuły.

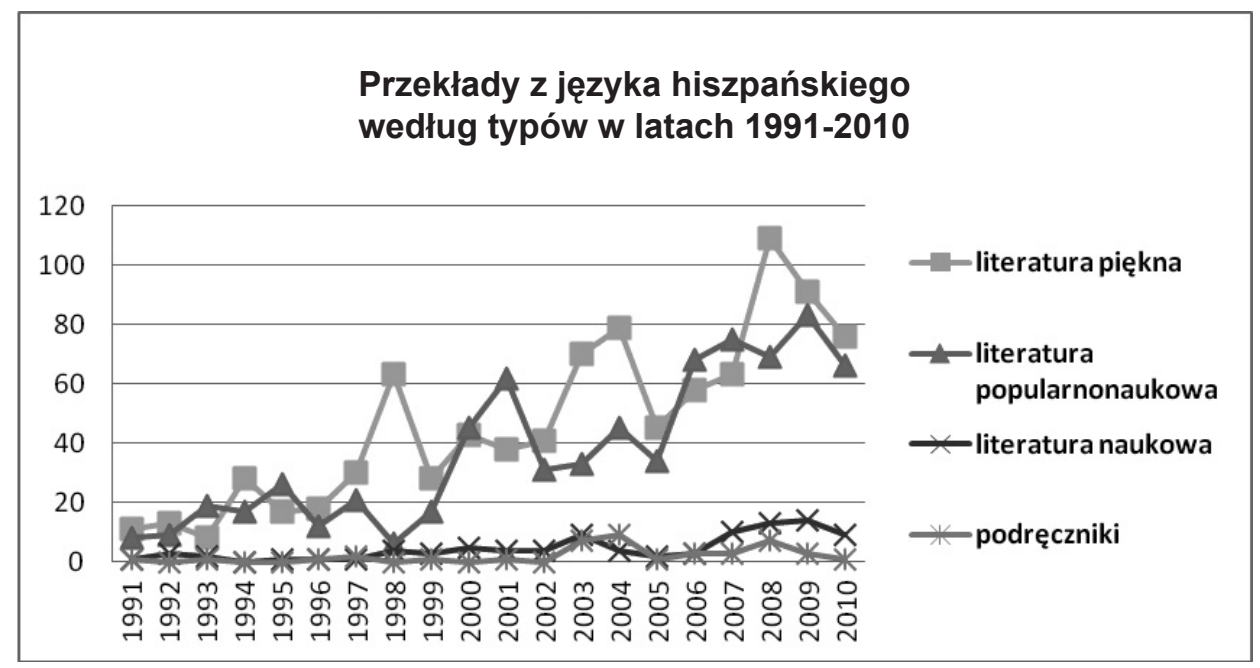

Wykres 11

Umiarkowanym zainteresowaniem w latach 1991-2010 cieszyły się przekłady dzieł o charakterze popularnonaukowym, których w ciagu dwóch dekad wydano 746 tytułów. Średnio w roku wydawano 35 tłumaczeń. W przypadku literatury popularnonaukowej dopiero koniec lat dziewięćdziesiątych przynosi ustabilizowany wzrost. Najmniejszym zainteresowaniem wydawców cieszyły się tłumaczenia podręczników i literatury naukowej. W latach 1991-2010 ukazało się zaledwie 41 przekładów podręczników. W pierwszym dziesięcioleciu opublikowano łącznie tylko 6 tytułów, w następnej dekadzie - 35. Niewiele było przekładów literatury naukowej, bo zaledwie 93 pozycje w ciagu 20 lat. Najwięcej, 14 tłumaczeń, ukazało się w 2009 r.

11 M. Gaszyńska-Magiera: Recepcja przekładów literatury iberoamerykańskiej w Polsce w latach 1945-2005 z perspektywy komunikacji międzykulturowej. Kraków 2011, s. 85.

12 Ibidem, s. 87. 


\section{Przekłady z języka rosyjskiego}

Kwestia obecności przekładów rosyjskojęzycznych w Polsce zawsze była bardzo złożona. W okresie powojennym literatura rosyjska zajmowała pierwsze miejsce pod względem liczby przekładów. Suma nakładów w latach 1945-1989 była bliska $110 \mathrm{mln}^{13}$. W ciagu ostatniego dwudziestolecia na polskim rynku wydawniczym ukazały się tylko 1794 tytuły przekładów rosyjskojęzycznych, co daje średnią roczną 89 pozycji (wykres 12).

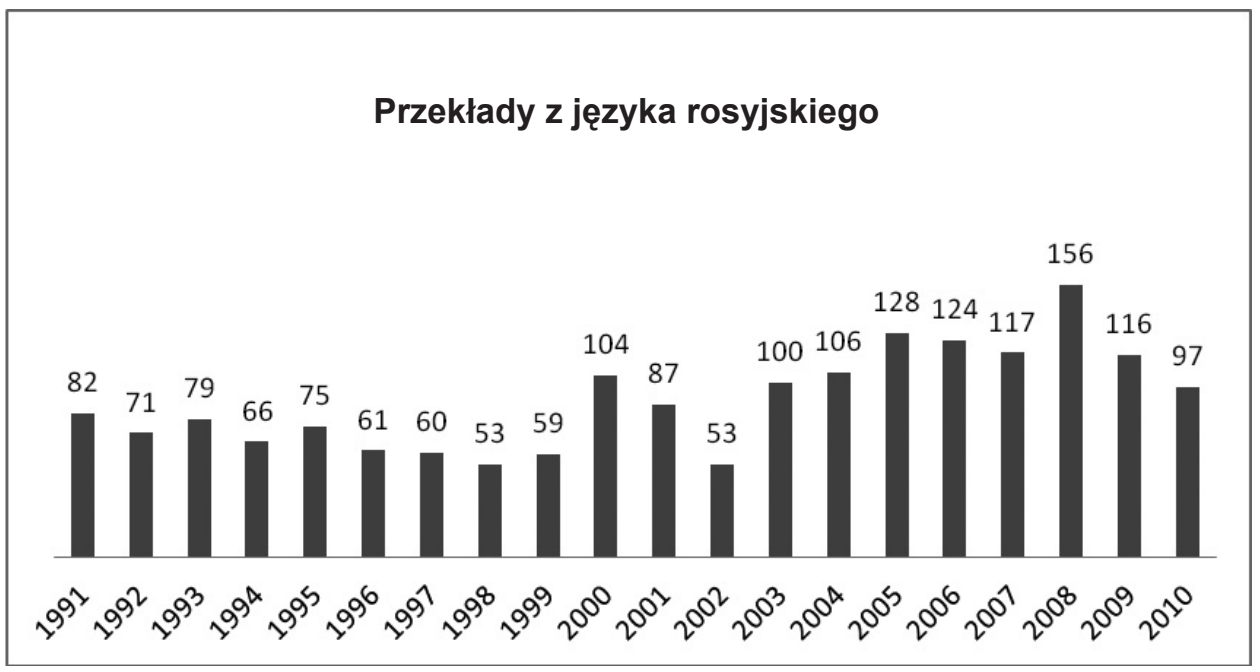

Wykres 12

W latach 1991-2000 ukazało się 710 tytułów, a w latach 2001-2010 liczba ta wzrosła do 1084. Lata dziewięćdziesiąte to dla wydawców trudny okres przekonania czytelników do przekładów z języka rosyjskiego, których wcześniej było w nadmiarze. Już następną dekadę cechuje umiarkowana stabilizacja. Rok 2008 przyniósł największe ożywienie - opublikowano wówczas 156 tytułów. Największy przyrost nastapił w 2003 r., w którym w stosunku do roku poprzedniego liczba przekładów wzrosła o 47 tytułów. Najchętniej tłumaczono literaturę piękną (wykres 13). Po zniesieniu cenzury w 1989 r. ukazały się oficjalnie tłumaczenia, które wcześniej znane były z „drugiego obiegu”. Pojawiły się przekłady Aleksandra Sołżenicyna, Siergieja Dowłatowa czy Władimira Maksimowa. Z klasyków najchętniej wydawano Fiodora Dostojewskiego, Lwa Tołstoja i Antona Czechowa ${ }^{14}$. W latach 1996-2000 ukazało się 18 wydań dzieł Michaiła Bułhakowa ${ }^{15}$. Ogólna liczba przekładów literatury pięknej wydanej w latach1991-2010 wyniosła 773 tytuły, średnio 38 rocznie. W latach 1991-2000 przetłumaczono 276 tytułów, natomiast w kolejnych 10 latach liczba wzrosła do 497.

${ }^{13}$ M. Semczuk: Literatura rosyjska w Polsce po 1989 r. „Recepcja. Transfer. Przekład” 2005, nr 1, s. 18.

${ }^{14}$ A. Hutnikiewicz, A. Lam: Literatura polska XX w...., op. cit., s. 530.

${ }^{15}$ M. Semczuk: Literatura rosyjska..., op. cit., s. 22. 


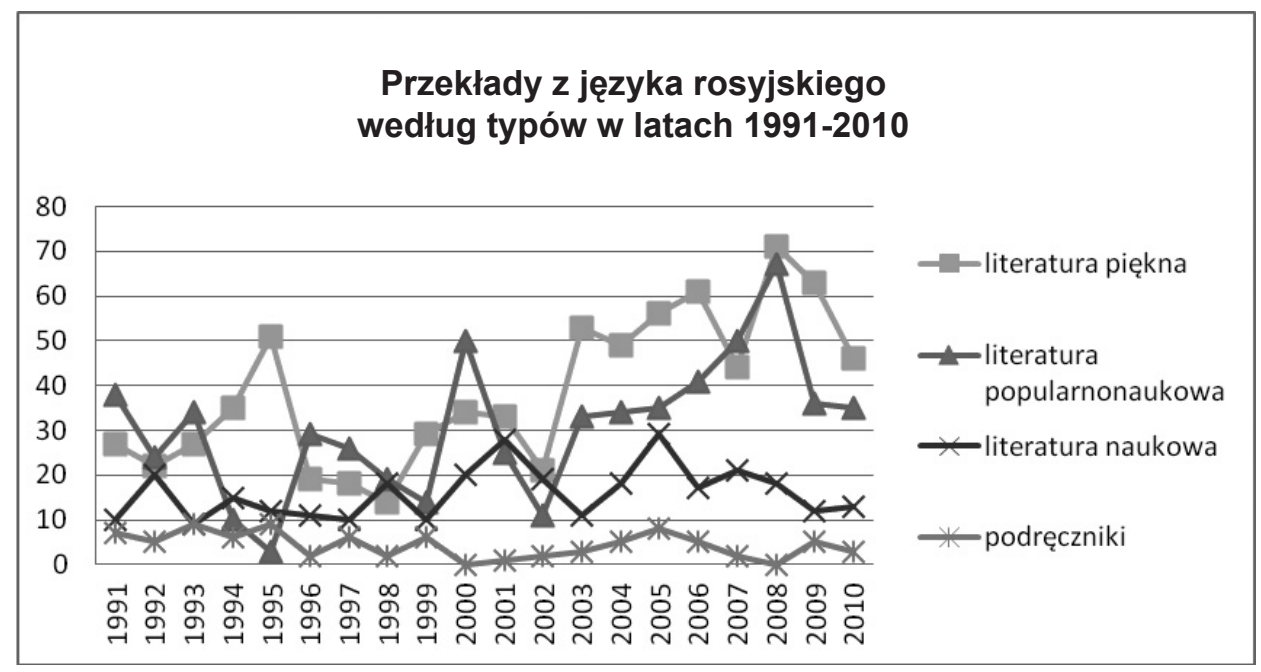

Wykres 13

Obserwuje się, że obecnie chętniej tłumaczona jest rosyjska literatura współczesna, a w grupie popularnych autorów znajdują się m.in. Wiktor Jerofiejew, Władimir Sorokin, Wiktor Pielewin, a także dramaturg Nikolaj Koleda, którego sztuki wystawiają polskie teatry ${ }^{16}$. Dużym zainteresowaniem cieszą przekłady literatury popularnonaukowej. Łącznie w latach 1991-2011 przetłumaczono 614 tytułów, 33 tytuły rocznie. Wykres przedstawia „chwiejność” lat dziewięćdziesiątych, w których liczba tłumaczeń wahała się od 3 w roku 1996, do 50 w roku 2000. W kolejnej dekadzie, z wyjątkiem roku 2008, liczba przekładów utrzymywała się na jednakowym poziomie. Umiarkowanym zainteresowaniem cieszyły się przekłady literatury naukowej. W latach 1991-2010 wydano łącznie 321 tytułów, średnio 20 pozycji. Choć w drugiej dekadzie nastapił pewien wzrost, to całe dwudziestolecie należy uznać za umiarkowane. Najwięcej publikacji przetłumaczono w roku 2005 - 29, najmniej w roku $1993-9$.

\section{Podsumowanie}

Na sytuację książki zagranicznej w Polsce po roku 1989 duży wpływ miały czynniki pozaliterackie: ekonomiczne, polityczne, obyczajowe. Niewątpliwie widoczna jest wysoka dynamika przekładów piśmiennictwa angielskojęzycznego, zarówno w odniesieniu do literatury pięknej, jak i literatury naukowej. Widoczny jest też bardzo głęboki spadek zainteresowania piśmiennictwem rosyjskojęzycznym, czego uzasadnienia na pewno należy szukać w historii kontaktów polsko-rosyjskich okresu powojennego. Jak się wydaje, rynek wydawniczy potwierdza zainteresowanie piśmiennictwem naukowym i popularnonaukowym niemieckojęzycznym. Chyba pewnego rodzaju zaskoczeniem może wydać się

${ }^{16}$ M. Wójcik: Enklawy wolności. Literatura rosyjska w Polsce 1956-1989. Kraków 2010, s. 335 . 
niski wskaźnik przekładów literatury pięknej francuskiej i hiszpańskojęzycznej, wypieranej wyraźnie przez beletrystykę angielskojęzyczną.

\section{Bibliografia}

1. Gaszyńska-Magiera M.: Recepcja przekładów literatury iberoamerykańskiej w Polsce w latach 1945-2005 z perspektywy komunikacji międzykulturowej. Kraków 2011.

2. Gołębiewski Ł.: Księgarnia bestsellerów. „Wprost” 1998, nr 40.

3. Hutnikiewicz A., Lam A.: Literatura polska XX w. Przewodnik encyklopedyczny. Tom 2. Warszawa 2000.

4. Kowalska M., Zawadzki A.: O kondycji literatury najnowszej. Polsko-francuskie spotkania literackie. Kraków 2006.

5. Łupak S.: Literatura jak futbol. „Gazeta Wyborcza” 2006, nr 115.

6. Połczyńska E., Załubska C.: Bibliografia przekładów z literatury niemieckiej na język polski 1800-2000. Tom 4: 1991-2000. Poznań 2005.

7. Raport opracowany na zlecenie Ministerstwa Kultury i Dziedzictwa Narodowego. [online]. Dostępny w World Wide Web: <http://www.ebib.info/images/file/ksiazka_raport_w_pelna_pdf.pdf>.

8. Semczuk M.: Literatura rosyjska w Polsce po 1989 r. „Recepcja. Transfer. Przekład” (1), $2005 \mathrm{nr} 1$.

9. Wójcik M.: Enklawy wolności. Literatura rosyjska w Polsce 1956-1989. Kraków 2010.

10. Skibińska E.: Kuchnia tłumacza. Studia o polsko-francuskich relacjach przekładowych. Kraków 2008.

\section{Summary}

The article presents dynamics of translations of foreign literature into Polish language in the years 1991-2010. The author focuses on English, French, Spanish, German, and Russian languages. Analysis was based on the "Polish Publishing in Figures" - official Polish publishing statistics. The author has studied translations in literature, science, popular science, and textbooks. 